\title{
Production of "Mel" Papaya Seedlings under the Application of Different Irrigation Depths
}

\author{
Vinicius de Souza Oliveira1, Wilian Rodrigues Ribeiro', Robson Prucoli Posse ${ }^{2}$, \\ Francielly Valani2, Rodrigo Amaro de Salles ${ }^{1}$, Wellington Sergio Oliveira ${ }^{2}$, \\ Jeniffer Ribeiro de Oliveira ${ }^{3}$, Geilson Silva Costa ${ }^{2}$, Sheila Cristina Prucoli Posse ${ }^{4}$, \\ Sara Dousseau Arantes ${ }^{5}$, Omar Schmildt ${ }^{3}$, Edilson Romais Schmildt ${ }^{3}$
}

${ }^{1}$ Federal University of Espírito Santo-Center for Agricultural Sciences and Engineering, Alegre, Brazil

${ }^{2}$ Federal Institute of Espírito Santo-Campus Itapina, Colatina, Brazil

${ }^{3}$ Federal University of Espírito Santo-Center Noth of Espírito Santo, São Mateus, Brazil

${ }^{4}$ Capixaba Institute for Research, Technical Assistance and Rural Extension, Vitória, Brazil

${ }^{5}$ Capixaba Institute for Research, Technical Assistance and Rural Extension, Regional Center for Rural Development, Linhares, Brazil

Email: souzaoliveiravini@gmail.com

How to cite this paper: de Souza Oliveira, V., Ribeiro, W.R., Posse, R.P., Valani, F., de Salles, R.A., Oliveira, W.S., de Oliveira, J.R., Costa, G.S., Posse, S.C.P., Arantes, S.D., Schmildt, O. and Schmildt, E.R. (2020) Production of "Mel" Papaya Seedlings under the Application of Different Irrigation Depths. Agricultural Sciences, 11, 921-931. https://doi.org/10.4236/as.2020.1110060

Received: August 14, 2020

Accepted: October 18, 2020

Published: October 21, 2020

Copyright $\odot 2020$ by author(s) and Scientific Research Publishing Inc. This work is licensed under the Creative Commons Attribution International License (CC BY 4.0).

http://creativecommons.org/licenses/by/4.0/

\section{(c) (i) Open Access}

\begin{abstract}
Water management is considered one of the most prevalent factors in the production of quality seedlings in commercial crops. Despite the benefits provided, the technique is still little used by irrigating users, who, for the most part, do not adopt any criteria for water use. Thus, aiming at the rational use of water resources and increasing the productive potential of seedlings, the objective of this study was to evaluate the effect of different irrigation depths on the production of Formosa "Mel" papaya seedlings (Carica papaya L.). The experiment took place in a greenhouse, located at the Federal Institute of Espírito Santo, Campus Itapina, in Colatina, ES. The treatments consisted of six irrigation depths corresponding to $4,6,8,10,12$ and 14 $\mathrm{mm} \cdot \mathrm{day}^{-1}$ adjusted in a completely randomized design, with 25 plants per treatment. The variables evaluated were: plant height, stem diameter, leaf area, dry mass of the aerial part, dry mass of the root system, total dry mass and Dickson's Quality index, 58 days after sowing in all experimental plots. At the end of the experiment, it was found that the $7.36 \mathrm{~mm} \cdot \mathrm{d}^{-1}$ irrigation depth provided better quality, in addition to lower water consumption, being the most recommended for the production of Formosa "Mel" papaya seedlings.
\end{abstract}

\section{Keywords}

Carica papaya L., Seedling Quality, Water Management 


\section{Introduction}

Brazil is one of the world's largest producers of papaya (Carica papaya L.) with a cultivated area of around 78,502,422 ha and production of 1,060,392 tons in 2018. The State of Espírito Santo stands out with a production close to 354,405 tons, corresponding to more than $33 \%$ of national production [1].

In papaya cultivation, the production of seedlings is one of the main stages for the success of a crop. Obtaining quality seedlings allows cultures to express their maximum genetic potential in the field [2]. One of the factors that most influence the achievement of quality seedlings is water availability [3]. However, the application of water is often done without technical grounds, limiting the potential development, growth and production of crops [4].

These factors: inadequate water management, subject plants to water stress, a condition caused by excess or lack of water in the soil, trigger a series of negative effects on important physiological processes of plants, causing the reduction of growth potential, in addition to favoring the appearance of diseases, excessive consumption of energy and fertilizers and leaching of nutrients [5] [6].

Thus, the replacement of water in the appropriate amount and at the right time is a decisive process for success in production systems [7]. However, for proper use of the technique, knowledge about the water need of crops is essential in order to guarantee satisfactory results and rational use of water resources [8] [9].

For papaya, water management protocols have already been reported in the production of seedlings of the cultivars "Rubi INCAPER 511" [10], "Tainung 01" [11] and "Golden THB" [12]. However, the different degrees of tolerance to the reduction of water humidity are associated with the individual's adaptation, which refers to a level of resistance genetically determined [13] or induced by natural selection, being fundamental application of specific studies to new materials, such as "Mel" papaya tree, a hybrid cultivar belonging to the Formosa group, with great market potential, due to high productivity, small size, uniformly shaped fruits and highly sweet pulp [14].

Given the economic importance of the crop and the lack of studies on water management in Formosa "Mel" papaya, the objective was to evaluate the effect of different irrigation depths on seedling production, in order to understand the relationship between irrigation management in papaya and improve the productive system aiming better quality for seedlings.

\section{Material and Methods}

The study took place in a greenhouse, at the Federal Institute of Espírito Santo, Campus Itapina, located in Colatina, a city in the Northwest region of the State of Espírito Santo, Brazil, with the geographical coordinates of $19^{\circ} 32^{\prime}$ South latitude and $40^{\circ} 37^{\prime}$ of longitude West, during the period from May $16^{\text {th }}$ to July $12^{\text {th }}$, 2018. The climate of the region according to the Köppen classification is of the tropical type Aw with predominance of rain during the summer and dry winter 
[15]. The minimum, maximum and average temperature and the average relative humidity inside the greenhouse were measured throughout the experiment by a Data Logger model 200 (WatchDog $^{\circ}$ ), as shown in Figure 1 and Figure 2.

Six individual environments with dimensions of $2.20 \mathrm{~m}$ long and $1.10 \mathrm{~m}$ wide were installed (Figure 3). Each room was covered with transparent plastic canvas on the sides, and inside it six GREEN MIST anti-drip nebulizers (NaanDanJain ${ }^{\circ}$ ) were placed, located $1 \mathrm{~m}$ above the seedlings and spaced $0.8 \mathrm{~m}$ apart. The environments had their irrigation controlled individually and electronically and maintained by a centrifugal pump with a power of $0.5 \mathrm{hp}$. The frequency of irrigation was distributed for 10 hours a day, with an operating pressure of $2 \mathrm{kgf}$ $\mathrm{cm}^{-2}$.

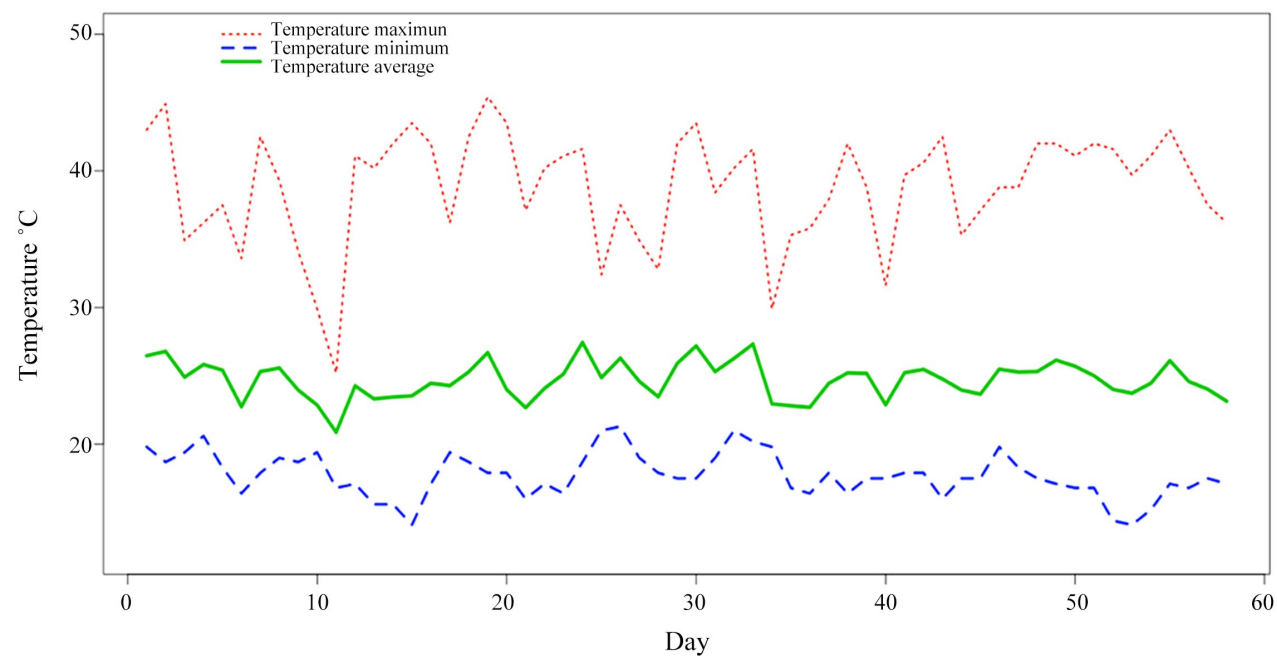

Figure 1. Monitoring of daily values of maximum, minimum and average temperatures in the greenhouse depending on the days after planting of the papaya seedlings, for the city of Colatina, Espírito Santo.

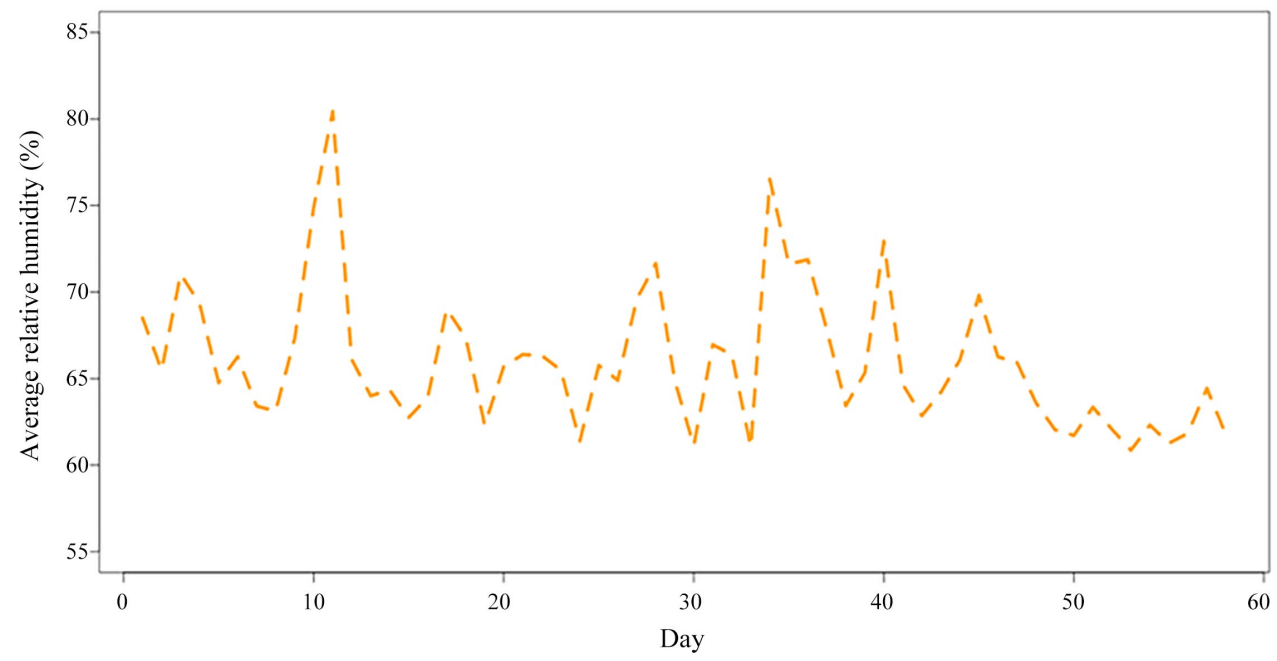

Figure 2. Monitoring of daily values of relative humidity in a greenhouse according to the days after planting of the papaya seedlings, for the city of Colatina, Espírito Santo. 


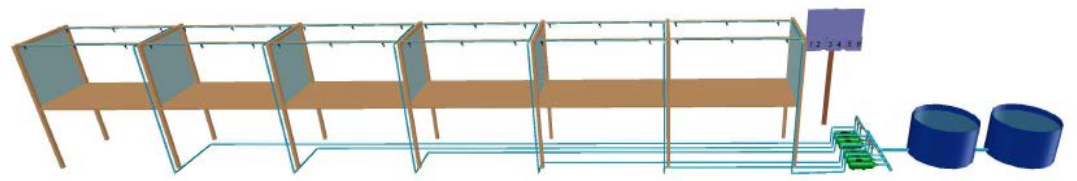

Figure 3. Sketch with the representation of the environments used for the experimentation.

The design used was completely randomized, with treatments consisting of six different irrigation depths corresponding to $4,6,8,10,12$ and $14 \mathrm{~mm} \cdot \mathrm{day}^{-1}$. Each treatment consisted of 25 plants, totaling 150 plants in the experimental field.

The seedlings were produced in tubes with a volume of $290 \mathrm{~cm}^{3}$ that were cleaned with sodium hypochlorite solution with a concentration of $2 \%$. Each one was filled with substrate Tropstrato $\mathrm{HT}^{\circ}$ Vegetables plus Osmocote Plus ${ }^{\circ}$ 15-9-12 $(3 \mathrm{M})$ in the dosage of $12 \mathrm{~kg} / \mathrm{m}^{3}$ with the following chemical composition: $\mathrm{N}=$ $15 \%$, (7\% ammonia and $8 \%$ nitrate), $\mathrm{P}_{2} \mathrm{O}_{5}=9 \%, \mathrm{~K}_{2} \mathrm{O}=12 \%, \mathrm{Mg}=1.3 \%, \mathrm{~S}=$ $5.9 \%, \mathrm{Cu}=0.05 \%, \mathrm{Fe}=0.46 \%, \mathrm{Mn}=0.06 \%$ and $\mathrm{Mo}=0.02 \%$. Two "Mel" papaya seeds were used per tube and thinning was carried out, keeping the seedling more vigorous after 15 days.

The end of the experiment occurred 58 days after sowing. Morphological characteristics were evaluated, such as: plant height $(\mathrm{PH})$; stem diameter (SD); leaf area (LA). Biomass: dry mass of the aerial part (DMAP); dry mass of the root system (DMRS); total dry mass (TDM). Quality: Dickson's Quality Index (DQI).

The plant height was measured with a graduated ruler, from the stem to the apical bud, in $\mathrm{cm}$. The stem diameter was measured with a caliper, in $\mathrm{mm}, 2 \mathrm{~cm}$ above the edge of the tube. The leaf area was determined with a LI-COR table model LI-3100C, in $\mathrm{cm}^{2}$. To obtain the dry mass values, initially, the seedlings were cut in the trunk region, close to the ground level, separating the relative mass of the aerial and the root parts. The materials were packed in paper bags and taken to a forced air circulation oven for 72 hours at a temperature of $65^{\circ} \mathrm{C}$, being subsequently weighed on a precision scale, thus obtaining the values of partitioned dry mass. The TDM was obtained by the product of the sum of DMAP and DMRS and the DQI determined according to Dickson et al. [16] as shown in Equation (1):

$$
\mathrm{DQI}=\frac{\mathrm{TDM}}{\frac{\mathrm{PH}}{\mathrm{SD}}+\frac{\mathrm{DMAP}}{\mathrm{DMRS}}}
$$

The data were submitted to analysis of variance $(\mathrm{p} \leq 0.05)$ and when the F test was significant, the regression analysis of quantitative variables was done. The models were chosen based on the significance of the regression coefficients, using the $t$ student test, at the level of $5 \%$ probability and by the coefficient of determination. The maximum points were determined from the first derivative of the equation. Statistical analyzes were performed using the R software with the stats data package [17]. 


\section{Results and Discussion}

After analysis of variance $(\mathrm{p} \leq 0.05)$ it was found that there was a significant effect for all evaluated characteristics, attesting that the applications of different irrigation depths influence the growth and quality of Formosa "Mel" papaya seedlings. In all variables, good representation of the phenomenon was obtained by statistical models and a high coefficient of determination $\left(\mathrm{R}^{2}\right)$.

In all the analyzed characteristics of the "Mel" papaya seedlings, there was a negative influence both for the deficit and the water excess generated by the smallest and largest irrigation depths, respectively. This fact was also observed in the production of papaya cultivars "Rubi INCAPER 511" [10], "Tainung 01" [11] and "Golden THB" [12].

The lowest results obtained at the ends of the curves, where the plants were subjected to low volumes of water $\left(2,4\right.$ and $\left.6 \mathrm{~mm} \cdot \mathrm{d}^{-1}\right)$ and high volume of water $\left(10.12\right.$ and $\left.14 \mathrm{~mm} \cdot \mathrm{d}^{-1}\right)$ are responses to water stress conditions, which are harmful to crops, thus explaining the adjustment of the quadratic model obtained in all variables studied.

To overcome such damage, under stress conditions, plants use mechanisms, responsible for adaptive processes, in response to unfavorable environment conditions. Among them, it worthy to be mentioned those of survival, which regulate growth, morphology, photosynthesis and stomatal opening [18]. These processes directly affect plants from their vegetative to reproductive growth [18].

It can be said that the smallest water depths were insufficient to meet the water demand of the seedlings, thus causing a decrease in their growth potential due to an induced water deficit.

According to Silva et al. [19], basically the first line of defense against the water deficit is stomatal closure, since the diffusive resistance of water vapor reduces perspiration. However, if this situation extends, it damages the photosynthetic capacity due to the reduction of $\mathrm{CO}_{2}$ supply. Due to the increase in the amount of water applied, a positive response is observed in the growth of the seedlings, until reaching the maximum point, establishing the ideal amount of water for irrigation. It is believed that this point corresponds to a moisture gradient that allows for maximum transpiration, and, consequently, growth.

With the increase in the amount of water again, an unfavorable condition is established, due to several factors related to hypoxia, leaching of nutrients, among others, again reducing the growth potential of the seedlings.

In Figure 4(a), the plant height $(\mathrm{PH})$ showed at the point of maximum height of $19.4 \mathrm{~cm}$ on the $9.03 \mathrm{~mm} \cdot \mathrm{d}^{-1}$ irrigation depth. The largest stem diameter (SD) was $5.01 \mathrm{~mm}$ in the $7.75 \mathrm{~mm} \cdot \mathrm{d}^{-1}$ irrigation depth (Figure $4(\mathrm{~b})$ ). The leaf area (LA) showed a maximum point adjustment of $112.8 \mathrm{~cm}^{2}$ in the $8.51 \mathrm{~mm} \cdot \mathrm{d}^{-1}$ irrigation depth (Figure 4(c)).

The value found for the dry mass of the aerial part (DMAP) at the maximum point was $0.86 \mathrm{~g}$ in the $7.98 \mathrm{~mm} \cdot \mathrm{d}^{-1}$ irrigation depth (Figure 5(a)), for the dry mass of the root system (DMRS) was $0.44 \mathrm{~g}$ in the $8.04 \mathrm{~mm} \cdot \mathrm{d}^{-1}$ (Figure $5(\mathrm{~b})$ ), for 
the total dry mass (TDM) at the maximum point of $1.29 \mathrm{~g}$ in the $8.01 \mathrm{~mm} \cdot \mathrm{d}^{-1}$ (Figure 5(c)) and the Dickson's quality index (DQI) showed a maximum of 0.22 in the $7.36 \mathrm{~mm} \cdot \mathrm{d}^{-1}$ (Figure $5(\mathrm{~d})$ ).

Water stress reduces cell turgor, decreasing cell expansion and multiplication, limiting plant growth and development [20]. In addition, under such conditions the synthesis of abscisic acid (ABA) can increase up to 50 times compared to normal conditions, being the most radical change from a plant hormone to an environmental stimulus. The production of this hormone is very efficient in stomatal closure, as it helps to reduce water losses due to the perspiration process [18].

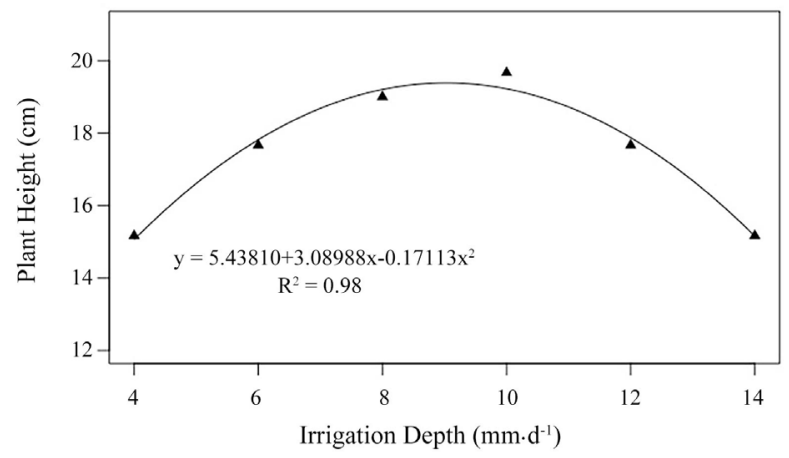

(a)

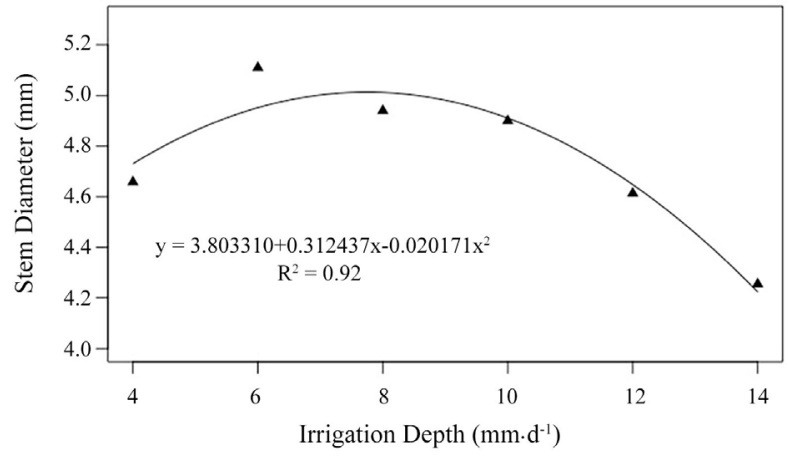

(b)

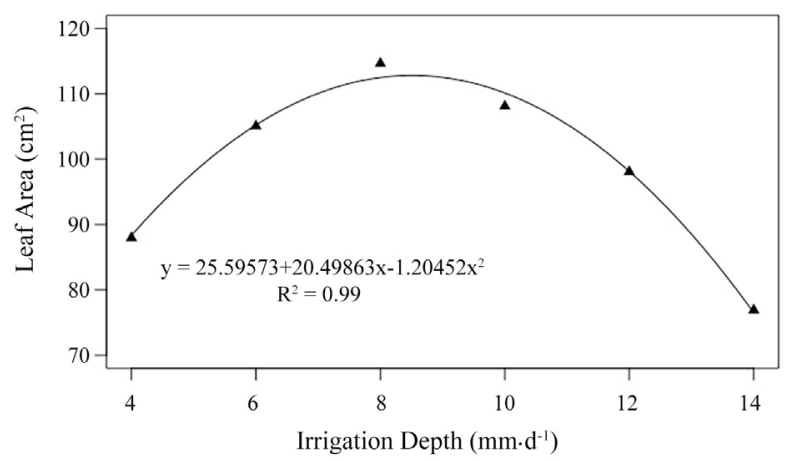

(c)

Figure 4. Effect of different irrigation depths on plant height $(\mathrm{PH})$, stem diameter (SD) and leaf area (LA) of Formosa "Mel" papaya seedlings. 


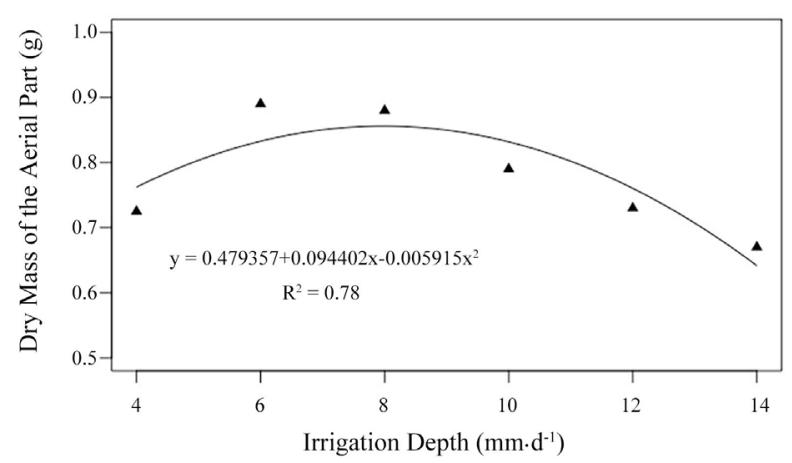

(a)

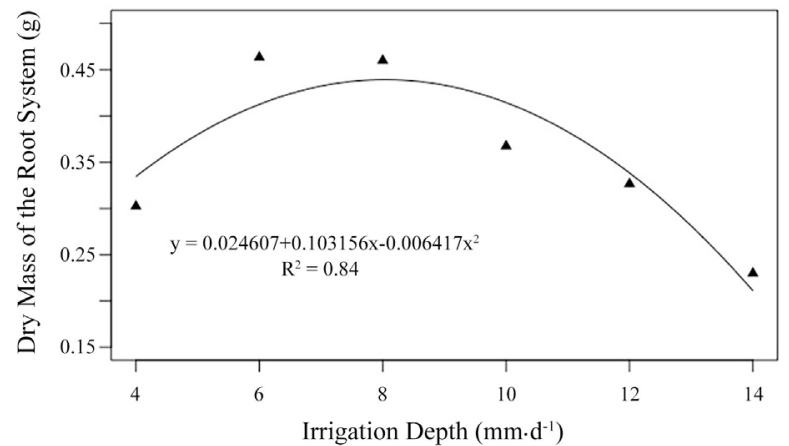

(b)

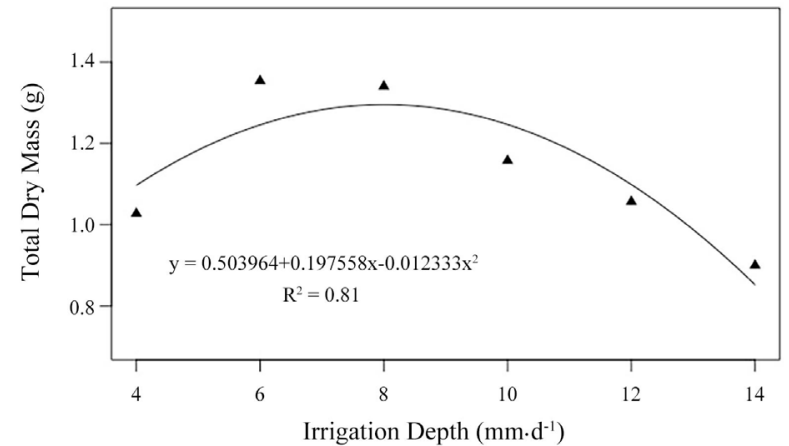

(c)

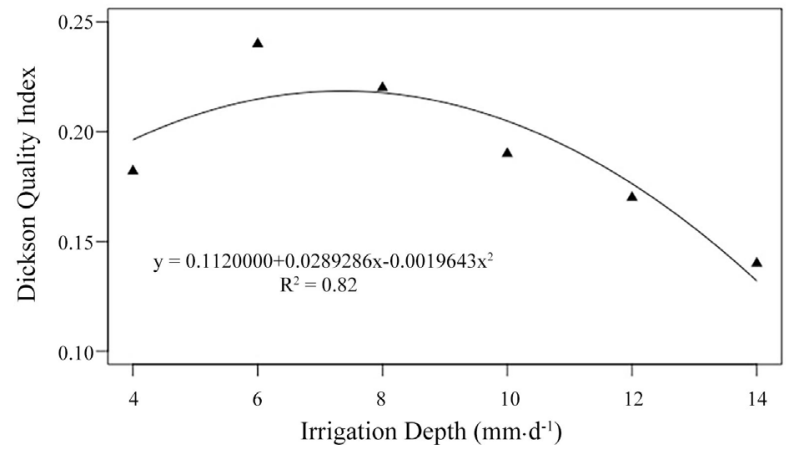

(d)

Figure 5. Effect of different irrigation depths on the dry mass of the aerial part (a), dry mass of the root system (b) total dry mass (c) and Dickson's quality index (d) of Formosa "Mel" papaya seedlings. 
In environments where the amount of water is in excess, a condition of hypoxia (low oxygen availability) is created in the roots, causing the plant to substitute respiration for fermentation and this alteration may generate a decrease in the amount of energy limiting the growth and development of plants [21]. Papaya is an extremely sensitive crop to lack of aeration in the soil, with a considerable reduction in physiological processes after 24 hours submitted to these environments, which can lead to the death of the plant if exposed to these conditions for two to four days [22]. In addition, as well as the lack of water, the excess induces ABA synthesis more accentuated in old, withered and inferior leaves, which is translocated to the newer leaves, leading to the closure of stomata and reducing photosynthesis [23].

One of the first defenses of plants to stressful conditions is the reduction of leaf area. Large leaves optimize the production of photosynthesis, however, they can be harmful to the growth of plants submitted to water deficit, since they have greater surface for perspiration, implying rapid depletion of soil water [18]. According to Melo et al. [24], in the production of papaya seedlings, a larger leaf area allows plants to have a higher rate of light absorption, which provides greater use for the process of photosynthesis and consequently an increase in photoassimilates, reflects in greater growth of stem height and diameter, in addition to the accumulation of dry biomass by plants.

In fact, it is possible to observe that there is a similar effect among all the characteristics evaluated in this study, where there was a gradual increase in the values up to the point of maximum technical efficiency, which is defined as the satisfactory demand for water resources, since then there is a decrease in the average values, with irrigation depths between 7.36 and $9.03 \mathrm{~mm} \cdot \mathrm{d}^{-1}$ providing better values for all analyzed characteristics. However, it should be noted that characteristics such as PH, SD, LA, DMAP and DMRS analyzed individually may not reflect the real quality of the seedlings, as nurserymen tend to select the highest seedlings, rejecting the smallest ones, however with greater vigor [25]. Thus, the DQI is the characteristic that best expresses the quality of seedlings, since in its formula it takes into account all parts of the plant [26].

The highest averages for the DQI were found in the $7.36 \mathrm{~mm} \cdot \mathrm{d}^{-1}$ irrigation depth, showing that the seedlings present higher quality under this water regime. According to Gomes et al. [27], seedlings with higher DQI values are more desirable because they are more lignified, which allows greater survival capacity when transplanted to the field. In addition, this irrigation depth was the one with the lowest water demand, which may result in lower production costs and reduce water consumption.

\section{Conclusion}

The $7.36 \mathrm{~mm} \cdot \mathrm{d}^{-1}$ irrigation depth provided better quality, in addition to lower water consumption, being the most recommended for the production of Formosa "Mel" papaya seedlings. 


\section{Acknowledgements}

CNPq, CAPES and FAPES for financial support.

\section{Conflicts of Interest}

The authors declare no conflicts of interest regarding the publication of this paper.

\section{References}

[1] Instituto Brasileiro De Geografia E Estatística IBGE (2020) Municipal Agricultural Production: Area Planted or Destined for Harvest, Area Harvested, Quantity Produced, Average Yield and Value of Production of Temporary and Permanent Crops. http://www.sidra.ibge.gov.br

[2] Weckner, F.C., Campos, M.C.C., Nascimento, E.P., Mantovanelli, B.C. and Nascimento, M.F. (2016) Evaluation of Papaya Seedlings under the Effect of Applying Different Compositions of Biofertilizers. Revista da Universidade Vale do Rio Verde, 14, 700-706. https://doi.org/10.5892/ruvrd.v14i1.2539

[3] Silva, C.J., Silva, C.A., Freitas, C.A., Golynski, A. and Golynski, A.A. (2015) Production and Growth of Baruzeiro Seedlings as a Function of Containers and Irrigation Depths. Irriga, 20, 652-666. https://doi.org/10.15809/irriga.2015v20n4p652

[4] Gruber, Y.B.G. (2006) Otimização da lâmina de irrigação na produção de mudas clonais de eucalipto (Eucalyptus urophylla x Eucalyptus grandis e Eucalyptus urophylla var. plathyphylla) Dissertação (Mestrado em Irrigação e Drenagem)—Escola Superior de Agricultura Luiz de Queiroz, Universidade de São Paulo, Piracicaba.

[5] Sá, N.S.A., Pereira, G.M., Alvarenga, M.A.R., Mattioli, W. and Carvalho, J.A. (2005) Behavior of Tomato Crop under Different Soil Water Tensions in a Greenhouse. Revista Brasileira de Engenharia Agrícola e Ambiental, 9, 341-347. https://doi.org/10.1590/S1415-43662005000300008

[6] Silva, C.A., Dourado Neto, D., Silva, C.J. and Melo, B. (2015) Development of Surinam Cherry Seedlings as a Function of Irrigation Depths in Two Container Sizes. Irriga, 20, 638-651.

[7] Gonçalves, M.S., Ribeiro, W.R, Pinheiro, A.A, Martins, C.A., Cóser, A., Reis, E.F. and Garcia, G.O. (2018) Productive Aspects of Tropical Grasses under Different Soil Water Stresses. Journal of Experimental Agriculture International, 23, 1-12. https://doi.org/10.9734/JEAI/2018/41808

[8] Santos, G.O., Déa, T.K.G., Abreu, L.D., Cabral, R.F., Thiesen, A.C.O., Carvalho, R. and Diniz, R.G. (2019) Irrigated Agriculture Management: Technical Instructions to Vegetable Growers-Open Market Vendors. Revista Conexão UEPG, 15, 193-198. https://doi.org/10.5212/Rev.Conexao.v.15.i2.0010

[9] Ribeiro, W.R., Pinheiro, A.A., Ferreira, D.S., Gonçalves, M.S., Aparecida, C. and Reis, E.F. (2018) Water Deficit as a Limiting Factor to the Initial Growth of Coffee Conilon Variety Diamante. Journal of Experimental Agriculture International, 22, 1-11. https://doi.org/10.9734/JEAI/2018/41156

[10] Oliveira, V.S., Posse, R.P., Pinheiro, A.P.B., Costa, G.S., Malikouski, R.G., Morais, A.L. and Schmildt, E.R. (2018) Effect of Irrigation Depths on the Growth of Papaya Seedlings. Journal of Experimental Agriculture International, 29, 1-9. https://doi.org/10.9734/JEAI/2019/45917

[11] Posse, R.P., Valani, F., Oliveira, V.S., Kirmse, R., Partelli, R.L., Pancieri, G.S. and 
Costa, G.S. (2019) Growth and Quality of Papaya “Tainung 01" Seedlings Submitted to Different Irrigation Depths. Journal of Experimental Agriculture International, 30, 1-11. https://doi.org/10.9734/JEAI/2019/46331

[12] Posse, R.P., Valani, F., Oliveira, V.S., Silva, L.M., Silveira, S.S., Silva, S.M.F. and Costa, G.S. (2019) Growth and Quality of Papaya "Golden THB” Seedlings Cultivated under Different Irrigation Depths. Journal of Experimental Agriculture International, 29, 1-10. https://doi.org/10.9734/JEAI/2019/46286

[13] Cavalcante, A.C.R., Cavallini, M.C. and Lima, N.R.C.B. (2009) Stress Due to Water Deficit in Forage Plants. Documentos 89. Empresa Brasileira de Pesquisa Agropecuária. Sobral-CE, $47 \mathrm{p}$.

[14] Denver Sementes (2020) Mamão Mel. https://www.formosamel.com

[15] Alvares, C.A., Stape, J.L, Sentelhas, P.C., Gonçalves, J.L.M. and Sparovek, G. (2014) Köppen's Climate Classification Map for Brazil. Meteorologische Zeitschrift, 22, 711-728. https://doi.org/10.1127/0941-2948/2013/0507

[16] Dickson, A., Leaf, A.L. and Hosner, J.F. (1960) Quality Appraisal of White Spruce and White Pine Seedling Stock in Nurseries. Forest Chronicles, 36, 10-13. https://doi.org/10.5558/tfc36010-1

[17] R Core Team (2020) R: A Language and Environment for Statistical Computing. R Foundation for Statistical Computing, Vienna.

[18] Taiz, L., Zeiger, E., Moller, I.M. and Murphy, A. (2017) Plant Physiology and Development. 6th Edition, Artmed, Porto Alegre, 858 p.

[19] Silva, M.A.V., Nogueira, R.J.M.C., Oliveira, A.F. and Santos, V.F. (2008) Stomatal Responses and Dry Matter Yield in Young Aroeira Plants Submitted to Different Water Levels. Revista Arvore, 32, 335-344. https://doi.org/10.1590/S0100-67622008000200016

[20] Padilha, N.S., Silva, C.J., Pereira, S.B., Silva, J.A.N., Heid, D.M., Bottega, S.P. and Scalon, S.P.Q. (2016) Initial Growth of Physic Nut Submitted to Different Water Regimes in Dystrophic Haplustox. Ciência Florestal, 26, 513-521. https://doi.org/10.5902/1980509822752

[21] Posse, R.P., Partelli, R.L., Oliveira, V.S., Trindade, I.M., Silveira, S.S., Silva, S.M.F.S., Posse, S.C.P., Souza, C.A.S., Schmildt, O. and Schmildt, E.R. (2019) Morphological Analysis of Cacao Seedlings Cultivar CCN51 under Different Irrigation Depths. International Journal of Development Research, 9, 29211-29215.

[22] Trindade, A.V. (2000) Papaya, Production: Technical Aspects. Embrapa Mandioca e Fruticultura, Brasília, Comunicado para transferência de tecnologia, $77 \mathrm{p}$.

[23] Taiz, L. and Zeiger, E. (2009) Plant Physiology. 4th Edition, Artmed, Porto Alegre, $819 \mathrm{p}$.

[24] Melo, A.S., Costa, C.X., Brito, M.E.B., Viégas, P.R.A. and Silva Júnior, C.D. (2007) Production of Papaya Seedlings in Different Substrates and Phosphorus Levels. Revista Brasileira de Ciências Agrárias, 2, 257-261. https://doi.org/10.5039/agraria.v2i4a1838

[25] Fonseca, E.P., Valéri, S.V., Miglioranza, É., Fonseca, N.A.N. and Couto, L. (2002) Target Seedlings of Trema micrantha (L.) Blume Grown under Different Periods of Shading. Revista Arvore, 26, 515-523. https://doi.org/10.1590/S0100-67622002000400015

[26] Silva, A.K., Costa, E., Santos, E.L.L., Benett, K.S.S. and Benett, C.G.S. (2013) Production of Papaya Seedlings under Thermal Reflector Screen and Substrates. Revista Brasileira de Ciências Agrárias, 8, 42-48. https://doi.org/10.5039/agraria.v8ila1996 
[27] Gomes, J.M., Couto, L., Leite, H.G., Xavier, A. and Garcia, S.L.R. (2003) Growth of Eucalyptus grandis Seedlings Produced in Different Sized Tubes and N-P-K' Fertilization. Revista Árvore, 27, 113-127.

https://doi.org/10.1590/S0100-67622003000200001 